\title{
Damages and Reparation in Energy Related Investment Treaty Arbitrations
}

Interpreting and Applying Rules of Customary International Law Regarding State Responsibility

\author{
Cees Verburg \\ Attorney-at-Law, Pels Rijcken, The Netherlands \\ Fellow, Groningen Centre of Energy Law and Sustainability, \\ University of Groningen, Groningen, The Netherlands \\ cees.verburg@pelsrijcken.nl
}

\begin{abstract}
International investment tribunals are frequently required to interpret and apply rules of Customary International Law (CIL) in investor-State disputes. This article examines how investor-State tribunals, in particular those constituted on the basis of the Energy Charter Treaty (ECT), have interpreted the CIL 'full reparation' standard regarding damages and reparation. By reference to ЕСт jurisprudence it is established that tribunals often utilize teleological interpretive tools to give content to this norm. Furthermore, some critical comments are made concerning the manner in which ECT tribunals subsequently apply the 'full reparation' standard. It is argued that the combination of the commonly adopted approaches to interpretation and application may explain why investors are occasionally capable of obtaining significant amounts of compensation in these public law disputes.
\end{abstract}

\section{Keywords}

full reparation - teleological interpretation - arbitration - Energy Charter Treaty State responsibility 
Over the last three decades international investment law has established itself as one of the most important subfields of international law: in the 199o's hundreds - if not thousands - of investment treaties were concluded, a development that was followed by a surge in investment disputes starting in the late 9o's that continues until this day. ${ }^{1}$ Most of these disputes are settled through international arbitration and predominantly arise in the relationship between foreign investors and host States. Since these arbitrations are largely governed by public international law, arbitrators are often required to interpret and apply rules of general international law, including Customary International Law (CIL). In this regard, one can think of rules of treaty law - either with a treaty as source (the Vienna Convention on the Law of Treaties) or as CIL. ${ }^{2}$ Another area of general international law that is often relevant in investment arbitration is the law of State responsibility as enshrined in the 2001 Articles on Responsibility of States for Internationally Wrongful Acts of the International Law Commission (hereinafter, the ILC Articles), to the extent that they codify CIL. ${ }^{3}$

This article will analyse how investment tribunals have interpreted CIL norms from the latter category, more specifically those concerning damages and reparation. In investment arbitration, damages awarded for

1 Marc Bungenberg, Jörn Griebel, Stephan Hobe and August Reinisch, "General Introduction to International Investment Law” in M. Bungenberg, J. Griebel, S. Hobe and A. Reinisch (eds.), International Investment Law - A Handbook (2015) pp. 1-5.

2 Bruno Simma and Dirk Pulkowski, "The Worlds, but Not Apart: International Investment Law and General International Law" in M. Bungenberg, J. Griebel, S. Hobe and A. Reinisch (eds.), International Investment Law - A Handbook (2015) p. 363. August Reinisch, "The Interpretation of International Investment Agreements" in M. Bungenberg, J. Griebel, S. Hobe and A. Reinisch (eds.), International Investment Law - A Handbook (2015) p. 373. Landesbank Baden-Württemberg and others v. Kingdom of Spain, ICSID Case No. ARB/15/45, Decision on the "Intra-EU" Jurisdictional Objection, 25 February 2019, para. 112. Noble Ventures, Inc. v. Romania, ICSID Case No. ARB/o1/11, Award, 12 October 2005, para. 50. The Canadian Cattlemen for Fair Trade v. United States of America, UnCitral, Award on Jurisdiction, 28 January 2008, para. 46.

3 Bruno Simma and Dirk Pulkowski, "The Worlds, but Not Apart: International Investment Law and General International Law" in M. Bungenberg, J. Griebel, S. Hobe and A. Reinisch (eds.), International Investment Law - A Handbook (2015) pp. 364-366. James Crawford and Simon Olleson, "The Application of the Rules of State Responsibility" in M. Bungenberg, J. Griebel, S. Hobe and A. Reinisch (eds.), International Investment Law - A Handbook (2015) pp. 415-420. M.C.I. Power Group L.C. and New Turbine, Inc. v. Republic of Ecuador, ICsid Case No. ARB/o3/6, Award, 31 July 2007, para. 42. Cargill, Incorporated v. United Mexican States, ICSID Case No. ARB(AF)/o5/2, Award, 18 September 2009, para. 381. Masdar Solar \& Wind Cooperatief U.A. v. Kingdom of Spain, ICSID Case No. ARB/14/1, Award, 16 May 2018, para. $55^{\circ}$. 
internationally wrongful acts by the host State can be rather significant. ${ }^{4}$ As an illustration: when the Russian oil company Yukos was driven into bankruptcy by the Russian Federation, a tribunal constituted under the Energy Charter Treaty (ECT) awarded the majority shareholders of Yukos, which held approximately 6o percent of the shares in the company, USD 50 bln in damages since Russia violated Art. 13 of the ЕСт. ${ }^{5}$ Before the European Court of Human Rights (ECtHR), the Yukos company was awarded EUR 1,9 bln for violations of Art. 6 of the European Convention on Human Rights (ECHR) and Art. 1 Protocol 1 to the ECHR. ${ }^{6}$ Given the multitude to which the majority shareholders of Yukos were entitled under the ECT in comparison to what the company - in its entirety was entitled to under the ECHR, one may ponder what warrants this very significant difference. Is it the difference in the applicable substantive law? Do investment tribunals adopt different approaches to the quantification of damages than judges at the ECtHR? Or has it anything to do with the applicable rules regarding damages and reparation? In relation to this last aspect, the ECT tribunal applied the CIL rules of the ILC Articles - which require 'full reparation' - while under the ECH R 'just satisfaction' was required on the basis of Art. 41 ECHR. ${ }^{7}$ Even though it is not the purpose of this article to identify the cause of this substantial difference in the Yukos cases, it does demonstrate that 'full reparation' can require the payment of a very significant amount of taxpayer's money to foreign investors.

Instead, the purpose of this article is to analyse how investment tribunals, specifically those constituted under the ECT, have interpreted the CIL standard

4 Diana Rosert, "The Stakes Are High: A Review of the Financial Costs of Investment Treaty Arbitration" (2014, IISD) p. 4. Suzy H. Nikièma, "Compensation for Expropriation" (2013, IISD) p. 10.

5 Hulley Enterprises Limited (Cyprus) v. The Russian Federation, UnCITRAL, PCA Case No. 2005o3/AA226, Final Award, 18 July 2014, para. 1827. Yukos Universal Limited (Isle of Man) v. The Russian Federation, uncitral, PCA Case No. 2005-04/AA227, Final Award, 18 July 2014, para. 1827. Veteran Petroleum Limited (Cyprus) v. The Russian Federation, UnCITRAL, PCA Case No. 2005-05/AA228, Final Award, 18 July 2014, para. 1827.

6 Case of OAO Neftyanaya Kompaniya Yukos v Russia (Application No. 14902/o4), Judgment of 20 September 2011. Case of OAO Neftyanaya Kompaniya Yukos v Russia (Application No. 14902/04), Judgment on Just Satisfaction of 31 July 2014.

7 Hulley Enterprises Limited (Cyprus) v. The Russian Federation, UnCITRAL, PCA Case No. 2005-03/AA226, Final Award, 18 July 2014, paras. 1586-1593. Yukos Universal Limited (Isle of Man) v. The Russian Federation, UnCitral, PCA Case No. 2005-04/AA227, Final Award, 18 July 2014, paras. 1586-1593. Veteran Petroleum Limited (Cyprus) v. The Russian Federation, unCitral, PCA Case No. 2005-05/AA228, Final Award, 18 July 2014, paras. 1586-1593. Case of OAO Neftyanaya Kompaniya Yukos v Russia (Application No. 14902/o4), Judgment on Just Satisfaction of 31 July 2014, para. 7. It has to be mentioned in this regard that both the 'full reparation' and the 'just satisfaction' norm embody the principle of restitutio ad integrum. 
of 'full reparation.'8 Thus, the present author will attempt to answer the following question: "What interpretive tools have been used by ECT tribunals to interpret the 'full reparation' standard as prescribed by CIL in cases of an internationally wrongful act?" This examination is expressly limited to awards rendered under the ЕСт since the applicable law in ЕСт cases will largely be the same. ${ }^{9}$ According to Art. 26(6) ECT, tribunals 'shall decide the issues in dispute in accordance with this Treaty and applicable rules and principles of international law. ${ }^{\prime 10}$ Other considerations to keep the scope of this analysis restricted to the ЕСт are: the fact that it is a highly relevant investment treaty because of its multilateral scope with more than 5 o Contracting Parties. Also, it is the most often invoked treaty with investment provisions in existence and it applies specifically to the energy sector where the various interests - including financial interests - are often rather significant. ${ }^{11}$

In order to answer the research question, this article will be structured as follows. Section 2 will briefly describe the context in which this article is set and introduce the ECT and relevant norms of the ILC Articles. Subsequently, section 3 will analyse ECT awards where tribunals discussed the topic of reparation and damages. As said, the main purpose of this article is to identify the tools of interpretation (i.e. grammatical, teleological etc.) that have been utilized by Ест tribunals when interpreting CIL. ${ }^{12}$ This means that, in the lifecycle' of rules of CIL, the emphasis of this article will not be on the formation of relevant rules of CIL, nor will it be on the 'inductive' process of identifying their existence. ${ }^{13}$ Rather, this article will focus on the 'deductive' process of the interpretation of the relevant CIL norm. ${ }^{14}$ In section 4 it will be argued that in the 'life-cycle' of rules of CIL, an important third stage should not be

8 Irmgard Marboe, "The System of Reparation and Questions of Terminology" in M. Bungenberg, J. Griebel, S. Hobe and A. Reinisch (eds.), International Investment Law A Handbook (2015) pp. 1034-1040.

On different applicable law clauses in investment treaties, see: Ole Spiermann, "Investment Arbitration: Applicable Law" in M. Bungenberg, J. Griebel, S. Hobe and A. Reinisch (eds.), International Investment Law - A Handbook (2015) pp. 1385-1389. Irmgard Marboe, Damages in Investor-State Arbitration: Current Issues and Challenges (1st ed., 2018) pp. 8-18.

Article 26(6), the Energy Charter Treaty (adopted 17/12/1994, entered into force 16/04/1998).

11 Thomas Roe and Matthew Happold, Settlement of Investment Disputes Under the Energy Charter Treaty (1st ed., 2011) p. 8.

12 Alexander Orakhelashvili, The Interpretation of Acts and Rules in Public International Law (1st ed., 2008) pp. 497-499.

13 Panos Merkouris, "Interpreting the Customary Rules on Interpretation" 19 International Community Law Review (2017) pp. 134-137.

Ibid p. 136. 
overlooked. In the authors view, this is shown by arbitral practice regarding the interpretation of the 'full reparation' standard. Finally, this article will end with a conclusion.

Since this article examines the interpretation of CIL norms in the context of ECT arbitration, this section will briefly introduce both the ECT as well as the relevant norms of CIL as codified in the ILC Articles.

\subsection{The Energy Charter Treaty}

The ECT is a multilateral trade and investment agreement concluded in the early 1990's with 54 Contracting Parties that is aimed at establishing a 'legal framework in order to promote long-term cooperation in the energy field. ${ }^{15}$ In addition to regulating trade and transit, the treaty also contains an investment chapter that 'aims to strengthen the rule of law on energy issues.'16 To that end, it contains substantive standards of investment protection that, amongst others, provide for fair and equitable treatment, non-discrimination, no expropriation without compensation, and a clause that guarantees the sanctity of contracts. ${ }^{17}$

Besides establishing the minimum standard of treatment that investors should receive, the ECT also contains an investor-State dispute settlement clause. This allows investors to enforce the standards of investment protection through the domestic courts of the host State, investment arbitration, or any other previously agreed dispute settlement procedure. ${ }^{18}$ In practice, an overwhelming majority of the foreign investors invokes the arbitration clause. ${ }^{19}$

15 Article 2, the Energy Charter Treaty (adopted 17/12/1994, entered into force 16/04/1998).

16 Rafael Leal-Arcas, "Introduction" in Rafael Leal-Arcas (ed.), Commentary on the Energy Charter Treaty (2018) p. 1.

17 Articles 10 and 13, the Energy Charter Treaty (adopted 17/12/1994, entered into force 16/o4/1998). Thomas Roe and Matthew Happold, Settlement of Investment Disputes Under the Energy Charter Treaty (1st ed., 2011) pp. 107-135. Diego Mejia-Lemos, "Article 10 - Promotion, Protection and Treatment of Investments" in Rafael Leal-Arcas (ed.), Commentary on the Energy Charter Treaty (2018). Diego Mejia-Lemos, "Article 13 Expropriation" in Rafael Leal-Arcas (ed.), Commentary on the Energy Charter Treaty (2018).

18 Article 26(2), the Energy Charter Treaty (adopted 17/12/1994, entered into force 16/04/1998).

19 There are more than 130 known ЕСт investment arbitration cases while, to the best of the authors knowledge, only three disputes have been brought before the domestic courts of host States. 
Concerning damages and reparation, the ECT - like most investment treaties - provides little guidance to adjudicators. ${ }^{20}$ Regarding expropriation, Art. 13 ECT states that for an expropriation to be lawful 'the payment of prompt, adequate and effective compensation' which amounts to the fair market value of the investment is required. ${ }^{21}$ However, this standard does not necessarily apply to unlawful expropriations nor to breaches of any other investment protection provision of the ЕСT, including those of Art. 10 which are frequently and successfully - invoked. ${ }^{22}$

Furthermore, on the basis of Art. 26(8) ECT, awards 'concerning a measure of a sub-national government or authority of the disputing Contracting Party shall provide that the Contracting Party may pay monetary damages in lieu of any other remedy granted. ${ }^{23}$ This implies that tribunals may award pecuniary as well as non-pecuniary remedies. ${ }^{24}$ However, in practice tribunals are very reluctant to award non-pecuniary remedies, either since ordering a host State

20 Mohammad Ammar Al-Bahloul v. The Republic of Tajikistan, scc Case No. v (o64/2008), Final Award, 8 June 2010, para. 41. Noah Rubins, Vasuda Sinha and Baxter Roberts, "Approaches to Valuation in Investment Treaty Arbitration" in Christina L. Beharry (ed.), Contemporary and Emerging Issues on the Law of Damages and Valuation in International Investment Arbitration (2018) p. 171.

21 Article 13(1), the Energy Charter Treaty (adopted 17/12/1994, entered into force 16/04/1998).

22 Hulley Enterprises Limited (Cyprus) v. The Russian Federation, UnCITRAL, PCA Case No. 2005-03/AA226, Final Award, 18 July 2014, para. 1765. Yukos Universal Limited (Isle of Man) v. The Russian Federation, UnCitral, PCA Case No. 2005-04/AA227, Final Award, 18 July 2014, para. 1765. Veteran Petroleum Limited (Cyprus) v. The Russian Federation, UNCITRAL, PCA Case No. 2005-05/AA228, Final Award, 18 July 2014, para. 1765. Ioannis Kardassopoulosv. The Republic of Georgia, ICsID Case No. ARB / 05/18, Award, 3 March 2010, paras. 502-503 and 532. Eiser Infrastructure Limited and Energía Solar Luxembourg S.à.r.l. v. Kingdom of Spain, ICSID Case No. ARB $/ 13 / 36$, Award, 4 May 2017, para. 420. Novenergia II - Energy \& Environment (SCA) (Grand Duchy of Luxembourg), SICAR v. The Kingdom of Spain, sCC Case No. 2015/063, Final Award, 15 February 2018, para. 804. Masdar Solar \& Wind Cooperatief U. A. v. Kingdom of Spain, ICSID Case No. ARB/14/1, Award, 16 May 2018, para. 548. Greentech Energy Systems A/S, et al v. Italian Republic, sCC Case No. v 2015/095, Final Award, 23 December 2018, paras. 544-548. Foresight Luxembourg Solar 1 S.Á.R.L., et al. v. Kingdom of Spain, scc Case No. 2015/15o, Final Award, 14 November 2018, para. 432. ${ }_{9} R E N$ Holding S.a.r.l v. Kingdom of Spain, ICSID Case No. ARB/15/15, Award, 31 May 2019, para. 373. Nykomb Synergetics Technology Holding AB v. The Republic of Latvia, scc, Arbitral Award, 16 December 2003, para. 5.1. Khan Resources Inc., Khan Resources B. V., and Cauc Holding Company Ltd. v. The Government of Mongolia, UnCITRAL, PCA Case No. 2011o9, Award on the Merits, 2 March 2015, para. 368.

23 Article 26(8), the Energy Charter Treaty (adopted 17/12/1994, entered into force 16/04/1998). Emphasis added.

24 Anna de Luca, "Non-Pecuniary Remedies Under the Energy CharterTreaty" 3 Transnational Dispute Management (2015). Mohammad Ammar Al-Bahloul v. The Republic of Tajikistan, sCC Case No.v (064/20o8), Final Award, 8 June 2010, para. 41. 
to bring its domestic laws and regulations in conformity with its ECT obligations may significantly infringe on its sovereign right to regulate its domestic affairs or because it may be impractical or impossible in light of the factual circumstances of the case. ${ }^{25}$ Moreover, an award that grants monetary compensation to the investor may be significantly easier to enforce outside the jurisdiction of the respondent State. ${ }^{26}$

In that regard, and contrary to the ECHR for example, the ЕCT does not contain a lex specialis concerning remedies which obliges arbitrators to deviate from the general CIL rules on this topic in case of an internationally wrongful act by the host State. ${ }^{27}$

\subsection{The ILC Articles on State Responsibility}

Since the ECT is silent on many questions regarding remedies in cases of internationally wrongful acts, tribunals often refer to the ILC Articles. ${ }^{28}$ The ILC Articles were adopted in May 2001 by the ILC and the General Assembly of the United Nations subsequently took note of them, annexed the text to a Resolution and 'recommended it to all governments without prejudice to their future adoption or the appropriate action. ${ }^{29}$

25 Chin Leng Lim, Jean Ho and Martins Paparinskis, International Investment Law and Arbitration - Commentary, Awards and Other Materials (1st ed., 2018) p. 403. Irmgard Marboe, "The System of Reparation and Questions of Terminology" in M. Bungenberg, J. Griebel, S. Hobe and A. Reinisch (eds.), International Investment Law - A Handbook (2015) p. 1036. Eiser Infrastructure Limited and Energía Solar Luxembourg S.à r.l. v. Kingdom of Spain, ICSID Case No. ARB/13/36, Award, 4 May 2017, para. 425. Masdar Solar \& Wind Cooperatief U.A. v. Kingdom of Spain, ICSID Case No. ARB/14/1, Award, 16 May 2018, paras. 553-563. Antin Infrastructure Services Luxembourg S.à.r.l. and Antin Energia Termosolar B. V. v. Kingdom of Spain, ICSID Case No. ARB/13/31, Award, 15June 2018, paras. 631-638. Petrobart Limited $v$. The Kyrgyz Republic, scc Case No. 126/2003, Arbitral Award, 29 March 2005, para. 9(a). AES Corporation and Tau Power B.V. v. Republic of Kazakhstan, ICSID Case No. ARB/10/16, Award, 1 November 2013, para. 466. Cube Infrastructure Fund SIVAC and others v. Kingdom of Spain, ICSID Case No. ARB/15/2O, Decision on Jurisdiction, Liability and Partial Decision on Quantum, 19 February 2019, para. 46o. RWE Innogy GmbH and RWE Innogy Aersa S.A.U. v. Kingdom of Spain, ICSID Case No. ARB/14/34, Decision on Jurisdiction, Liability and Certain Issues of Quantum, 30 December 2019, para. 685. Watkins Holdings S.à.r.l. and others v. Kingdom of Spain, ICSID Case No. ARB $/ 15 / 44$, Award, 21 January 2020, para. 674.

26 Hardy Exploration \& Production (India), Inc. v. Government of India, Ministry of Petroleum \& Natural Gas, Civ. Action No. 16-140 (D.D.C. 7 June 2018).

27 Irmgard Marboe, Damages in Investor-State Arbitration: Current Issues and Challenges (1st ed., 2018) p. 13 .

28 See section 3.2. below.

29 James Crawford, State Responsibility - the General Part (1st ed., 2013) p. 41. General Assembly, Resolution 56/83, 12 December 2001 (A/RES/56/83). 
Even though the ILC Articles at present remain a document that is not legally binding per se, their value is widely recognized in the practice of international courts and tribunals as reflecting CIL on this topic, either in whole or in part..$^{30}$ For the purposes of this article, the most relevant provisions are Arts. 31, 35, and 36. On the basis of Art. 31:

1. The responsible State is under an obligation to make full reparation for the injury caused by the internationally wrongful act.

2. Injury includes any damage, whether material or moral, caused by the internationally wrongful act of a State.

According to the ILC Articles, 'full reparation' is thus the applicable norm. The ILC Articles hereby restate the principle that had been applied by the Permanent Court of International Justice (PCIJ) in the Chorzów Factory case and which has received the approval of international courts and tribunals ever since:

The essential principle contained in the actual notion of an illegal act - a principle which seems to be established by international practice and in particular by the decisions of arbitral tribunals - is that reparation must, as far as possible, wipe out all the consequences of the illegal act and reestablish the situation which would, in all probability, have existed if that act had not been committed. ${ }^{31}$

30 James Crawford, State Responsibility - the General Part (1st ed., 2013) p. 43. Irmgard Marboe, "The System of Reparation and Questions of Terminology" in M. Bungenberg, J. Griebel, S. Hobe and A. Reinisch (eds.), International Investment Law - A Handbook (2015) pp. 1034-1035. For statements that the ILC Articles (not limited to matters related to damages, compensation, and remedies) codify CiL, see: Noble Ventures, Inc. v. Romania, ICSID Case No. ARB/O1/11, Award, 12 October 2005, para. 69. Biwater Gauff (Tanzania) Ltd. v. United Republic of Tanzania, ICSID Case No. ARB/05/22, Award, 24 July 2008, para. 773. Duke Energy Electroquil Partners \& Electroquil S.A. v. Republic of Ecuador, ICsid Case No. ARB/o4/19, Award, 18 August 2008, para. 468. Railroad Development Corporation v. Republic of Guatemala, ICSID Case No. ARB/07/23, Award, 29 June 2012, para. 26o. Application of the Convention on the Prevention and Punishment of the Crime of Genocide (Bosnia and Herzegovina v. Serbia and Montenegro), Judgment, I.C.J. Reports 2007, p. 43, para. 401.

31 Case Concerning the Factory at Chorzów (Germany v. Poland), Claim for Indemnity (Merits), Judgment of 13 September 1928, PCIJ Series A (1928), No. 17, p. 47. See also: Application of the Convention on the Prevention and Punishment of the Crime of Genocide (Bosnia and Herzegovina v. Serbia and Montenegro), Judgment, I.C.J. Reports 2007, p. 43, para. 46o. M/V "SAIGA" (No. 2) (Saint Vincent and the Grenadines v. Guinea), Judgment, ITlos Reports 1999, p. Io, para. 170. Certain Activities Carried out by Nicaragua in the Border Area (Costa Rica v. Nicaragua) Judgment of 2 February 2018, Compensation owed 
After stating that 'full reparation' is the applicable standard, the three forms that reparation can take are subsequently listed in Art. 34 of the ILC Articles: restitution, compensation, and satisfaction. For this article, restitution and compensation are the most relevant forms.

Restitution is defined in Art. 35 as 'to re-establish the situation which existed before the wrongful act was committed, provided and to the extent that restitution' is not '(a) materially impossible; (b) does not involve a burden out of all proportion to the benefit deriving from restitution instead of compensation.'32 Under the law of State responsibility, restitution is considered a primary remedy while compensation is considered a secondary remedy. ${ }^{33}$ However, for the reasons stated above it is, in the context of investment arbitration, only seldom sought and rarely awarded. Instead, compensation is the more important remedy as addressed in Art. 36:

1. The State responsible for an internationally wrongful act is under an obligation to compensate for the damage caused thereby, insofar as such damage is not made good by restitution.

2. The compensation shall cover any financially assessable damage including loss of profits insofar as it is established.

The main point that becomes evident from Art. 36 is that financial damage has to be 'assessable' without specifying how the damage should be assessed. ${ }^{34}$ According to Crawford, the 'appropriate heads of compensable damage and the principles of assessment to be applied in quantification will vary depending on the primary obligation in question and the facts of the case. ${ }^{35}$

by the Republic of Nicaragua to the Republic of Costa Rica, I.C.J. Reports 2018, para. 29. Ahmadou Sadio Diallo (Republic of Guinea v. Democratic Republic of the Congo), Merits, Judgment, I.C.J. Reports 2010 (II), p. 691, para. 161. Avena and Other Mexican Nationals (Mexico v. United States of America), Judgment, I.C.J. Reports 2004 (I), p. 59, para. 119. Gabčikovo-Nagymaros Project (Hungary/Slovakia), Judgment, I.C.J. Reports 1997, p. 80, para. 150 .

See also: Pulp Mills on the River Uruguay (Argentina v. Uruguay), Judgment, I.C.J. Reports 2010 (I), p. 14, para. 273.

33 Irmgard Marboe, "The System of Reparation and Questions of Terminology" in M. Bungenberg, J. Griebel, S. Hobe and A. Reinisch (eds.), International Investment Law A Handbook (2015) p. 1036. James Crawford, State Responsibility - the General Part (1st ed., 2013) pp. 509-510.

34 Richard E. Walck, "Methods of Valuing Losses" in M. Bungenberg, J. Griebel, S. Hobe and A. Reinisch (eds.), International Investment Law - A Handbook (2015) p. 1045. Kaj Hobér, "The Energy Charter Treaty - An Overview" 8(3) The Journal of World Investment \& Trade (2007) p. 354.

James Crawford, State Responsibility - the General Part (1st ed., 2013) p. 519. 
This section will discuss how ECT tribunals have approached the matters of damages and reparation with the purpose of establishing the interpretive tools utilized to give content to the standard of full reparation. Obviously, only ECT awards where a violation of the treaty has been established are considered. At present, nearly 3 Е ЕСт awards that are publicly available addressed the issues of damages and reparation.

\subsection{Deviant Approaches to Damages}

Even though numerous ECT tribunals have adopted fairly comparable approaches to reparation and damages, there are - as always - the odd ones out.

For example, in the Energoalliancev. Moldova case, the tribunal merely came up with a number that 'simply stating' equalled 'the costs of Claimant's investment before the violation by Respondent of its obligations under the ест.'36 No reference was made to the applicable standard. In fact, when discussing interest - a matter regulated in the ILC Articles itself as part of the 'full reparation' standard - the tribunal considered that the UNIDROIT Principles were 'expedient in this case. ${ }^{37}$ The tribunal thus applied a very different set of rules than one might expect since the claimant proposed so and the respondent did not object. ${ }^{38}$

In the RREEF $v$. Spain case, the tribunal explicitly rejected the 'full reparation' standard. According to the tribunal, it would be an 'illogical' standard in light of the facts of the case. ${ }^{39}$ This is an interesting conclusion given the fact that numerous ЕCT tribunals in cases against Spain - most of which are factually comparable - have had little problems with applying the full reparation standard, as the RREEF tribunal itself also acknowledged..$^{40}$ One can question whether the RREEF tribunal had to deviate from the 'full reparation' standard. In the RWE Innogy $v$. Spain case, for instance, the tribunal adopted a reasoning

36 Energoalliance Ltd. v. the Republic of Moldova, UnCitral, Award, 23 October 2013, para. 384 .

37 Ibid, para. 419.

38 Ibid, paras. 414 and 419.

39 RREEF Infrastructure (G.P.) Limited and RREEF Pan-European Infrastructure Two Lux S. à r. l.v. Kingdom of Spain, ICSID Case No. ARB /13/3o, Decision on Responsibility and on the Principles of Quantum, 30 November 2018, para. 515.

Id. 
that led to a comparable outcome as the RREEF case while applying the full reparation standard. ${ }^{41}$

\subsection{The Most Common Approach}

Despite the decisions of the tribunals in Energoalliance and RREEF, most ECT tribunals have adopted a comparable approach which incorporates several (if not all) of the following steps.

Firstly, many tribunals establish that the ЕСт does not contain provisions regulating reparation and damages in the case of an internationally wrongful act and, therefore, conclude that CIL applies. ${ }^{42}$ This determination may, however, be based on the shared view of the disputing parties on this matter. ${ }^{43}$

Secondly, many tribunals subsequently identify the applicable norm. Several norms of CIL are identified in practice. Most often reference is made to Art. 31 of the ILC Articles specifically or, sometimes, as a general reference

$41 \quad R W E$ Innogy GmbH and RWE Innogy Aersa S.A.U. v. Kingdom of Spain, ICSID Case No. ARB/14/34, Decision on Jurisdiction, Liability and Certain Issues of Quantum, 3o December 2019, paras. 729-742.

42 OperaFund Eco-Invest SICAV PLC and Schwab Holding AG v. Kingdom of Spain, ICSID Case No. ARB $/ 15 / 36$, Award, 6 September 2019, para. 6o9. SolEs Badajoz GmbH v. Kingdom of Spain, ICSID Case No. АRB/15/38, Award, 31 July 2019, para. 476. 9 REN Holding S.a.r.l v. Kingdom of Spain, ICSID Case No. ARB/15/15, Award, 31 May 2019, para. 373. Foresight Luxembourg Solar 1 S.Á.R.L., et al. v. Kingdom of Spain, sCC Case No. 2015/15o, Final Award, 14 November 2018, para. 432. Greentech Energy Systems A/S, et al v. Italian Republic, scc Case No. V 2015/095, Final Award, 23 December 2018, para. 548. Antin Infrastructure Services Luxembourg S.à.r.l. and Antin Energia Termosolar B.V. v. Kingdom of Spain, ICSID Case No. ARB/13/31, Award, 15 June 2018, paras. 659-66o. Masdar Solar \& Wind Cooperatief U.A. v. Kingdom of Spain, ICSID Case No. ARB/14/1, Award, 16 May 2018, para. 548. Novenergia II - Energy \& Environment (SCA) (Grand Duchy of Luxembourg), SICAR $v$. The Kingdom of Spain, sCc Case No. 2015/063, Final Award, 15 February 2018, para. 805. Eiser Infrastructure Limited and Energía Solar Luxembourg S.à.r.l. v. Kingdom of Spain, ICSID Case No. ARB $/ 13 / 36$, Award, 4 May 2017, para. 420. Ioannis Kardassopoulos v. The Republic of Georgia, ICSID Case No. ARB/o5/18, Award, 3 March 2010, para. 532. Mohammad Ammar Al-Bahloul v. The Republic of Tajikistan, scc Case No. v (064/2008), Final Award, 8 June 2010, paras. 40-42. Watkins Holdings S.à.r.l. and others v. Kingdom of Spain, ICSID Case No. ARB/15/44, Award, 21 January 2020, paras. 672-673. Nykomb Synergetics Technology Holding AB v. The Republic of Latvia, scc, Arbitral Award, 16 December 2003, para. 5.1.

43 Khan Resources Inc., Khan Resources B. V., and Cauc Holding Company Ltd.v. The Government of Mongolia, UnCitral, PCA Case No. 2011-09, Award on the Merits, 2 March 2015, paras. 368-370. InfraRed Environmental Infrastructure GP Limited and others v. Kingdom of Spain, ICSID Case No. ARB/14/12, Award, 2 August 2019, para. 510. The PV Investors v. Spain, UnCitral, PCA Case No. 2012-14, Final Award, 28 February 2020, para. 669. Watkins Holdings S.à.r.l. and others v. Kingdom of Spain, ICSID Case No. ARB/15/44, Award, 21 January 2020, para. 673 . 
to 'full reparation' or 'the Chorzów Factory standard'. ${ }^{44}$ Again, at times this may be a non-contested issue in the proceedings. ${ }^{45}$ Besides reference to Art. 31 ILC Articles, tribunals also refer to Arts. 35,36 , and $38 .{ }^{46}$

44 OperaFund Eco-Invest SICAV PLC and Schwab Holding AG v. Kingdom of Spain, ICSID Case No. ARB /15/36, Award, 6 September 2019, para. 6og. SolEs Badajoz GmbHv. Kingdom of Spain, ICSID Case No. ARB/15/38, Award, 31 July 2019, paras. 476-477. CEF Energia BV v. Italian Republic, scc Case No. 158/2015, Award, 16 January 2019, para. 265. Greentech Energy Systems A/S, et al v. Italian Republic, scc Case No. V 2015/o95, Final Award, 23 December 2018, para. 548. Foresight Luxembourg Solar 1 S.Á.R.L., et al. v. Kingdom of Spain, scc Case No. 2015/15o, Final Award, 14 November 2018, paras. 433-435. Antin Infrastructure Services Luxembourg S.à.r.l. and Antin Energia Termosolar B.V. v. Kingdom of Spain, ICSID Case No. ARB/13/31, Award, 15 June 2018, paras. 662-664. Novenergia II - Energy \& Environment (SCA) (Grand Duchy of Luxembourg), SICAR v. The Kingdom of Spain, sCC Case No. 2015/063, Final Award, 15 February 2018, paras. 806-808. Eiser Infrastructure Limited and Energía Solar Luxembourg S.à.r.l. v. Kingdom of Spain, ICSID Case No. ARB /13/36, Award, 4 May 2017, paras. 421-424. Anatolie Stati, Gabriel Stati, Ascom Group SA and Terra Raf Trans Traiding Ltd v. Kazakhstan, sCC Case No. v 116/2010, Award, 19 December 2013, para. 1527. Ioannis Kardassopoulos v. The Republic of Georgia, ICSID Case No. ARB/05/18, Award, 3 March 2010, para. 594. Mohammad Ammar Al-Bahloul v. The Republic of Tajikistan, scc Case No. v (064/2008), Final Award, 8 June 2010, paras. 42-43. Petrobart Limited v. The Kyrgyz Republic, scc Case No. 126/2003, Arbitral Award, 29 March 2005, para. 9(a). Hulley Enterprises Limited (Cyprus) v. The Russian Federation, UnCITRAL, PCA Case No. 2005-O3/AA226, Final Award, 18 July 2014, paras. 15871590. Yukos Universal Limited (Isle of Man) v. The Russian Federation, UNCITRAL, PCA Case No. 2005-04/AA227, Final Award, 18 July 2014, paras. 1587-159o. Veteran Petroleum Limited (Cyprus) v. The Russian Federation, UnCITrAL, PCA Case No. 2005-05/AA228, Final Award, 18 July 2014, paras. 1587-1590. Cube Infrastructure Fund SIVAC and others v. Kingdom of Spain, ICSID Case No. ARB/15/20, Decision on Jurisdiction, Liability and Partial Decision on Quantum, 19 February 2019, para. 459. RWE Innogy GmbH and RWE Innogy Aersa S.A.U. v. Kingdom of Spain, ICSID Case No. ARB/14/34, Decision on Jurisdiction, Liability and Certain Issues of Quantum, 3o December 2019, paras. 685 and 733-742. Watkins Holdings S.à.r.l. and others v. Kingdom of Spain, ICSID Case No. ARB/15/44, Award, 21 January 202O, paras. $673-677$.

45 NextEra Energy Global Holdings B.V. and NextEra Energy Spain Holdings B. V. v. Kingdom of Spain, ICSID Case No. ARB/14/11, Decision on Jurisdiction, Liability and Principles of Quantum, 12 March 2019, para. 642. 9REN Holding S.a.r.lv. Kingdom of Spain, ICSID Case No. ARB/15/15, Award, 31 May 2019, para. 373. Masdar Solar \& Wind Cooperatief U.A. v. Kingdom of Spain, ICSID Case No. ARB/14/1, Award, 16 May 2018, paras. 549-552. Khan Resources Inc., Khan Resources B.V., and Cauc Holding Company Ltd. v. The Government of Mongolia, UnCitral, PCA Case No. 2011-o9, Award on the Merits, 2 March 2015, paras. 369-370. Nykomb Synergetics Technology Holding AB v. The Republic of Latvia, scC, Arbitral Award, 16 December 2003, para. 5.1.

46 Masdar Solar \& Wind Cooperatief U.A. v. Kingdom of Spain, ICSID Case No. ARB/14/1, Award, 16 May 2018, paras. $55^{8}$ and 565. Novenergia II - Energy \& Environment (SCA) (Grand Duchy of Luxembourg), SICAR v. The Kingdom of Spain, scc Case No. 2015/063, Final Award, 15 February 2018, para. 808. Ioannis Kardassopoulos v. The Republic of Georgia, ICSID Case No. ARB/05/18, Award, 3 March 2010, paras. 532 \& 659. Mohammad Ammar Al-Bahloulv. The Republic of Tajikistan, scc Case No.v (064/2008), Final Award, 
Thirdly, after having established what the applicable norm is, most tribunals attempt to identify what 'full reparation' entails. It has to be noted, however, that a few tribunals seemingly go straight from identification of the norm to the application thereof without elaborating on the content. ${ }^{47}$

Those tribunals that do identify the content of the 'full reparation' norm often do so by reference to the PCIJ judgment from the Chorzów Factory case where it was held that 'reparation must, as far as possible, wipe out all the consequences of the illegal act and re-establish the situation which would, in all probability, have existed if that act had not been committed. ${ }^{48}$ This statement, or parts and/or variations thereof, were recalled by the tribunals in Petrobart v. Kyrgyz Republic, SolEs Badajoz v. Spain, Cube Infrastructure v. Spain, gRen Holding v. Spain, CEF Energia v. Italy, Greentech v. Italy, Foresight v. Spain, Antin v. Spain, Masdar v. Spain, Novenergia v. Spain, Eiser v. Spain, Anatolie Stati v. Kazakhstan, Kardassopoulos v. Georgia, Khan v. Mongolia, The PV Investors v. Spain, RWE Innogyv. Spain, Watkinsv. Spain and the Yukosv. Russian Federation cases. ${ }^{49}$ As stated by both the Khan v. Mongolia and CEF Energia v. Italy

8 June 2010, para. 43. Nykomb Synergetics Technology Holding AB v. The Republic of Latvia, SCC, Arbitral Award, 16 December 2003, para. 5.1. Hulley Enterprises Limited (Cyprus) v. The Russian Federation, unCitral, PCA Case No. 2005-03/AA226, Final Award, 18 July 2014, para. 159o. Yukos Universal Limited (Isle of Man) v. The Russian Federation, UNCITRAL, PCA Case No. 2005-04/AA227, Final Award, 18 July 2014, para. 159o. Veteran Petroleum Limited (Cyprus) v. The Russian Federation, unCitral, PCA Case No. 2005-05/AA228, Final Award, 18 July 2014, para. 159 o.

47 NextEra Energy Global Holdings B.V. and NextEra Energy Spain Holdings B.V. v. Kingdom of Spain, ICSID Case No. ARB/14/11, Decision on Jurisdiction, Liability and Principles of Quantum, 12 March 2019, para. 642. Nykomb Synergetics Technology Holding AB v. The Republic of Latvia, scc, Arbitral Award, 16 December 2003, para. 5.1.

48 Case Concerning the Factory at Chorzów (Germany v. Poland), Claim for Indemnity (Merits), Judgment of 13 September 1928, PCIJ Series A (1928), No. 17, p. 47.

49 Petrobart Limited v. The Kyrgyz Republic, scc Case No. 126/2003, Arbitral Award, 29 March 2005, para. 9(a). Cube Infrastructure Fund SIVAC and others v. Kingdom of Spain, ICSID Case No. ARB/15/2O, Decision on Jurisdiction, Liability and Partial Decision on Quantum, 19 February 2019, para. 459. 9 REN Holding S.a.r.l v. Kingdom of Spain, ICSID Case No. ARB /15/15, Award, 31 May 2019, para. 373. CEF Energia BVv. Italian Republic, sCC Case No. 158/2015, Award, 16 January 2019, para. 267. Greentech Energy Systems A/S, et al v. Italian Republic, scc Case No. v 2015/095, Final Award, 23 December 2018, para. 545. Foresight Luxembourg Solar 1 S.Á.R.L., et al. v. Kingdom of Spain, SCC Case No. 2015/150, Final Award, 14 November 2018, para. 434. Antin Infrastructure Services Luxembourg S.à.r.l. and Antin Energia Termosolar B.V. v. Kingdom of Spain, ICSID Case No. ARB/13/31, Award, 15 June 2018, para. 662. Masdar Solar \& Wind Cooperatief U.A. v. Kingdom of Spain, ICSID Case No. ARB /14/1, Award, 16 May 2018, para. 549. Novenergia II - Energy \& Environment (SCA) (Grand Duchy of Luxembourg), SICAR v. The Kingdom of Spain, SCC Case No. 2015/063, Final Award, 15 February 2018, para. 807. Eiser Infrastructure Limited and Energía Solar Luxembourg S.à r.l. v. Kingdom of Spain, ICSID Case No. ARB/13/36, Award, 4 May 2017, para. 422. Anatolie Stati, Gabriel Stati, Ascom Group SA and Terra Raf 
tribunals, this statement of the PCIJ sheds a light on the purpose of compensation in international law. ${ }^{50}$ As such, it can be considered as a form of teleological interpretation since it refers to the object and purpose of the norm.

Besides referring to the Chorzów Factory judgment, three Ест tribunals have also referred to the following consideration of the Vivendiv. Argentina tribunal:

Based on these principles [i.e., those pronounced in Factory at Chorzów], and absent limiting terms in the relevant treaty, it is generally accepted today that, regardless of the type of investment, and regardless of the nature of the illegitimate measure, the level of damages awarded in international investment arbitration is supposed to be sufficient to compensate the affected party fully and to eliminate the consequences of the state's action..$^{51}$

In a similar vein, the Antin v. Spain and Eiserv. Spain tribunals underlined that the investors were entitled to full reparation 'so as to remove the consequences of the wrongful act. 52

Trans Traiding Ltd v. Kazakhstan, scc Case No. v 116/2010, Award, 19 December 2013, para. 1527. Ioannis Kardassopoulos v. The Republic of Georgia, ICSID Case No. ARB/o5/18, Award, 3 March 2010, para. 594. Khan Resources Inc., Khan Resources B.V., and Cauc Holding Company Ltd. v. The Government of Mongolia, UnCITRAL, PCA Case No. 2011-o9, Award on the Merits, 2 March 2015, para. 370. Hulley Enterprises Limited (Cyprus) v. The Russian Federation, UnCitral, PCA Case No. 2005-03/AA226, Final Award, 18 July 2014, para. 1588. Yukos Universal Limited (Isle of Man) v. The Russian Federation, UNCITRAL, PCA Case No. 2005-04/AA227, Final Award, 18 July 2014, para. 1588. Veteran Petroleum Limited (Cyprus) v. The Russian Federation, UnCitral, PCA Case No. 2005-05/AA228, Final Award, 18 July 2014, para. 1588. SolEs Badajoz GmbHv. Kingdom of Spain, ICSID Case No. ARB B/15/38, Award, 31 July 2019, para. 476. The PV Investors v. Spain, UnCitral, PCA Case No. 201214, Final Award, 28 February 2020, para. 852. RWE Innogy GmbH and RWE Innogy Aersa S.A.U. v. Kingdom of Spain, ICSID Case No. ARB $/ 14 / 34$, Decision on Jurisdiction, Liability and Certain Issues of Quantum, 30 December 2019, para. 685. Watkins Holdings S.à.r.l. and others v. Kingdom of Spain, ICSID Case No. ARB/15/44, Award, 21 January 202O, paras. 673 and 677 .

50 CEF Energia BV v. Italian Republic, sCC Case No. 158/2015, Award, 16 January 2019, para. 267. Khan Resources Inc., Khan Resources B.V., and Cauc Holding Company Ltd. v. The Government of Mongolia, UnCitral, PCA Case No. 2011-o9, Award on the Merits, 2 March 2015, para. 37o.

51 Compañiá de Aguas del Aconquija S.A. and Vivendi Universal S.A. v. Argentine Republic, ICSID Case No. ARB $/ 97 / 3$, Award, 20 August 2007, para. 8.2.7. 9REN Holding S.a.r.l v. Kingdom of Spain, ICSID Case No. ARB/15/15, Award, 31 May 2019, para. 375. Foresight Luxembourg Solar 1 S.Á.R.L., et al. v. Kingdom of Spain, sCC Case No. 2015/150, Final Award, 14 November 2018, para. 436. Ioannis Kardassopoulos v. The Republic of Georgia, ICSID Case No. ARB/o5/18, Award, 3 March 2010, para. 533 .

Antin Infrastructure Services Luxembourg S.à.r.l. and Antin Energia Termosolar B.V. v. Kingdom of Spain, ICSID Case No. ARB/13/31, Award, 15 June 2018, para. 664. Eiser 
These statements could again be considered as a teleological interpretation of the full reparation standard since they emphasize that the level of compensation should eliminate or remove the consequences of the internationally wrongful act.

In addition to these statements that have been reiterated at various occasions, some tribunals have also added a few words of their own. For example, in the Greentech $v$. Italy case, Italy argued that the words 'as far as possible' as pronounced by the PCIJ, should actually be used by the tribunal to limit its effect by considering various circumstances of the case, all of which - according to Italy - should lead to a reduction in the amount of damages awarded to the investor. ${ }^{53}$ The tribunal did not agree with this construction and, quite to the contrary, held that the phrase 'as far as possible' means 'that a tribunal must do whatever it takes to ensure that full compensation is granted and the injured party is made whole. ${ }^{54}$ This may not only be a teleological interpretation of the norm but go even further: by emphasizing that the effectiveness of the norm should be ensured it may be an effet utile interpretation. ${ }^{55}$

A comparable point was made by the Cube Infrastructure $v$. Spain tribunal which held that ' $[\mathrm{t}] \mathrm{he}$ reparation due is the amount that wipes out the consequences of the illegal act. ${ }^{56}$ In Masdar $v$. Spain, the tribunal stressed that full reparation 'requires putting the investor into a position that would have existed but for the breach. ${ }^{57}$ Similarly, the Novenergia tribunal held that full reparation 'dictates that the aggrieved investor shall through monetary compensation be placed in the same situation it would have been but for the breaches of the State's international law obligations. ${ }^{58}$ In OperaFund $v$. Spain, the tribunal held that the full reparation standard 'implies putting Claimants

Infrastructure Limited and Energía Solar Luxembourg S.à r.l. v. Kingdom of Spain, ICSID Case No. ARB $/ 13 / 36$, Award, 4 May 2017, para. 424.

53 Greentech Energy Systems A/S, et al v. Italian Republic, scc Case No. v 2015/o95, Final Award, 23 December 2018, paras. 546-547.

54 Ibid, para. 548.

55 Céline Braumann and August Reinisch, "Effet Utile" in J. Klingler, Y. Parkhomenko and C. Salonidis (eds.), Between the Lines of the Vienna Convention - Canons and Other Principles of Interpretation in Public International Law (2019).

$5^{6}$ Cube Infrastructure Fund SIVAC and others v. Kingdom of Spain, ICSID Case No. ARB B/15/20, Decision on Jurisdiction, Liability and Partial Decision on Quantum, 19 February 2019, para. 461.

57 Masdar Solar \& Wind Cooperatief U.A. v. Kingdom of Spain, ICSID Case No. ARB/14/1, Award, 16 May 2018, paras. 565 and 578 .

58 Novenergia II - Energy \& Environment (SCA) (Grand Duchy of Luxembourg), SICAR v. The Kingdom of Spain, sCC Case No. 2015/063, Final Award, 15 February 2018, para. 808. 
in the same position they would have found themselves, had Respondent not breached the Ест.59

All of these statements emphasize the goal that the norm aims to achieve. As such they can be considered as a teleological interpretation of CIL. Sometimes an element of effectiveness is added. It is notable in that regard that no tribunal adopted a grammatical interpretation of 'full reparation'. After all, a reference to the grammatical meaning of the word 'full' which is 'not lacking or omitting anything; complete' can achieve the same result. ${ }^{60}$

In international law, interpreting rules of treaty law and CIL by reference to object and purpose is widely accepted. ${ }^{61}$ In the context of investment arbitration, it is actually so common that its usage has been called 'excessive. ${ }^{62}$ The principle of effective interpretation, often referred to as effet utile, is also an accepted principle of interpretation and also seemingly relied on in the context of reparation. ${ }^{63}$ Both effet utile and reference to object and purpose, which are closely related, can be considered as teleological interpretive tools. ${ }^{64}$

59 OperaFund Eco-Invest SICAV PLC and Schwab Holding AG v. Kingdom of Spain, ICSID Case No. ARB $/ 15 / 36$, Award, 6 September 2019, para. 6 og.

6o Lexico Dictionary, 'Full' <https://www.lexico.com/en/definition/full> accessed on 18/o7/2019.

61 Concerning the interpretation of treaties, it is part of Art. 31(1) of the Vienna Convention on the law of Treaties. Robert Kolb, The Law of Treaties - An Introduction (2016) pp. 145-146. Oil Platforms (Islamic Republic of Iran v. United States of America), Preliminary Objection, Judgment, I.C.J. Reports 1996, p. 803, paras. 27-28. LaGrand (Germany v. United States of America), Judgment, I.C.J. Reports 2001, p. 466, paras. 99-102. Concerning CIL, see: North Sea Continental Shelf Cases, Dissenting Opinion of Judge Tanaka, I.C.J. Reports 1969, p. 172 at p. 181.

62 Michael Waibel, "International Investment Law and Treaty Interpretation" in R. Hofmann and C. J. Tams (eds.), International Investment Law and General International Law - From Clinical Isolation to Systemic Integration? (2011) p. 3o. Andrew Newcombe and Lluís Paradell, Law and Practice of Investment Treaties - Standards of Treatment (1st ed., 2009) pp. $113-116$.

63 Céline Braumann and August Reinisch, "Effet Utile" in J. Klingler, Y. Parkhomenko and C. Salonidis (eds.), Between the Lines of the Vienna Convention-Canons and Other Principles of Interpretation in Public International Law (2019) p. 47. Noble Ventures, Inc. v. Romania, ICSID Case No. ARB/01/11, Award, 12 October 2005, para. 50. United States - Standards for Reformulated and Conventional Gasoline, wT/DS2/AB/2, Report of the Appellate Body, 29 April 1996, p. 23. Arbitration Regarding the Iron Rhine Railway between the Kingdom of Belgium and the Kingdom of the Netherlands, PCA Case No. 2003-02, Award, 24 May 2005, para. 49.

64 Andrew Newcombe and Lluís Paradell, Law and Practice of Investment Treaties - Standards of Treatment (1st ed., 2009) pp. 114-116. J. Romesh Weeramantry, Treaty Interpretation in Investment Arbitration (1st ed., 2012) para. 3.70. 
As becomes clear from the above, ЕCT tribunals prefer to utilize a teleological tool of interpretation in relation to the 'full reparation' standard of CIL. In the introduction a distinction was made between the stages of the 'life-cycle' of rules of CIL as stated by Merkouris. The first stage consists of the 'inductive' process of identifying that CIL rules exist while the second stage consists of the 'deductive' process of their interpretation, i.e., establishing the content and meaning of the rule. ${ }^{65}$ I would submit that an equally important third stage should not be overlooked, namely that of 'application' of the rule of CIL. Even though some might consider it impossible to distinguish between the interpretation and application of a norm, the stage of 'application' of the rules of CIL concerning reparation might hold the answer to the question that came up in the introduction: ${ }^{66}$ why did the shareholders of Yukos obtain such a high level of compensation in ECT arbitration in comparison to the ECtHR proceedings?

According to the ILC Articles, a host State which violates its obligations under the ECT vis-à-vis the investor is obliged to make full reparation. If compensation is the remedy granted, this 'shall cover any financially assessable damage including loss of profits insofar as it is established' and the 'reparation due is the amount that wipes out the consequences of the illegal act.' ${ }^{67}$ Aspects on which the ILC Articles contain little guidance concern the manner in which the damage has to be assessed/quantified and the date of valuation, the latter of which may particularly be relevant in cases of unlawful expropriation. ${ }^{68}$ The consequences of this lack of guidance, as well as the existence of the different

65 Panos Merkouris, "Interpreting the Customary Rules on Interpretation" 19 International Community Law Review (2017) pp. 134-137.

66 Anastasios Gourgourinis, "The Distinction Between Interpretation and Application of Norms in International Adjudication" 2(1) Journal of International Dispute Settlement (2011) pp. 31-32. Roscoe Pound, The Spirit of Common Law (1921) p. 179. Franklin Berman, "International Treaties and British Statutes" 26(1) Statute Law Review (2005) pp. 9-11. Case Concerning the Factory at Chorzów (Germanyv. Poland), Claim for Indemnity (Jurisdiction), Dissenting Opinion of Judge Ehrlich, PCIJ Series A (1927), No. 9, 35, p. 39. Empresas Lucchetti, S.A. and Lucchetti Peru, SA. v. The Republic of Peru, ICsid Case No. ARB/o3/4, Decision on Annulment, 5 September 2007, paras. 68-70. Waste Management, Inc. $v$. United Mexican States, ICSID Case No. ARB(AF)/oo/3, Award, 30 April 2004, para. 88.

67 Article 36(2), ILC Articles on State Responsibility (2001). Cube Infrastructure Fund SIVAC and others v. Kingdom of Spain, ICSID Case No. ARB/15/20, Decision on Jurisdiction, Liability and Partial Decision on Quantum, 19 February 2019, para. 461.

68 James Crawford, State Responsibility - the General Part (1st ed., 2013) p. 519. Richard E. Walck, "Methods of Valuing Losses" in M. Bungenberg, J. Griebel, S. Hobe and A. Reinisch (eds.), International Investment Law - A Handbook (2015) p. 1045. Kaj Hobér, "The Energy Charter Treaty - An Overview" 8(3) The Journal of World Investment \& Trade (2007) p. 354. 
stages of interpretation and application of a norm, can be illustrated by reference to ECT arbitration.

Concerning the date of valuation, in the Yukos cases for example, the tribunal held that - due to interplay between Arts. 35 and 36 of the ILC Articles the 'investors must enjoy the benefits of unanticipated events that increase the value of an expropriated asset up to the date of the decision, because they have a right to compensation in lieu of their right to restitution of the expropriated asset as of that date. ${ }^{69}$ Since the investors' damages at the date of expropriation in 2004 were estimated at roughly USD 22 bln while they amounted to nearly USD 67 bln at the date of the award, this 'novel' determination of the tribunal was definitely favourable for the investors. ${ }^{70}$ Taking into account that the value of oil companies is influenced by oil prices, the damages in oil related investment arbitrations may be highly volatile: almost directly after the Yukos awards had been rendered the oil prices would collapse from over USD 100 per barrel in the summer of 2014 to USD 26 per barrel in early $2016 .{ }^{71}$

In relation to the methods to assess damages, there are roughly speaking three categories of valuation methods that are commonly used by valuators:

$69 \quad$ Hulley Enterprises Limited (Cyprus) v. The Russian Federation, UnCITRAL, PCA Case No. 2005-03/AA226, Final Award, 18 July 2014, paras. 1766-1767. Yukos Universal Limited (Isle of Man) v. The Russian Federation, UnCITRAL, PCA Case No. 2005-04/AA227, Final Award, 18 July 2014, paras. 1766-1767. Veteran Petroleum Limited (Cyprus) v. The Russian Federation, UnCitral, PCA Case No. 2005-05/AA228, Final Award, 18 July 2014, paras. $1766-1767$. Emphasis added.

70 Ibid para. 1826. Irmgard Marboe, "Case Comment - Yukos Universal Limited (Isle of Man) v. the Russian Federation: Calculation of Damages in the Yukos Award: Highlighting the Valuation Date, Contributory Fault and Interest" 30(2) ICSID Review - Foreign Investment Law Journal (2015) p. 329. On the relevant valuation date, see: Noah Rubins, Vasuda Sinha and Baxter Roberts, "Approaches to Valuation in Investment Treaty Arbitration" in Christina L. Beharry (ed.), Contemporary and Emerging Issues on the Law of Damages and Valuation in International Investment Arbitration (2018) pp. 176-179. Floriane Lavaud and Guilherme Recena Costa, "Valuation Date in Investment Arbitration: A Fundamental Examination of Chorzów's Principles", 3 Journal of Damages in International Arbitration (2016), pp. 50-64. William Lieblich, "Determining the Economic Value of Expropriated Income-Producing Property in International Arbitrations", 8 Journal of International Arbitration (1991), pp. 72-75. Compañia del Desarrollo de Santa Elena S.A. v. Republic of Costa Rica, ICsid Case No. ARB/96/1, Award, 17 February 200o, paras. 78 and 83. ADC Affliate Limited and ADC \& ADMC Management Limited v. The Republic of Hungary, ICSID Case No. ARB/o3/16, Award of the Tribunal, 2 October 2006, paras. 496-497.

71 In the annulment proceedings in the Yukos cases, the Court of Appeal in The Hague eventually refused to set aside the Yukos awards for an alleged improper manner to quantify damages, stating that under international law, investment tribunals have a 'wide discretion when it comes to the quantification of damages.' See: Court of Appeal The Hague, Yukos v. Russian Federation, 18 February 2O2O, ECLI:GHDHA:2O2O:234, para. 6.4.5. 
'(a) cost- or asset-based approaches, (b) market- or transaction based methods and (c) income-based methods. ${ }^{72}$ This latter category, and more specifically certain methods falling in this category such as the Discounted Cash Flow (DCF) method, ${ }^{73}$ were long met with scepticism by international courts and (investment) tribunals because of their speculative nature. ${ }^{74}$ This was also noted by the ILC. ${ }^{75}$ Nevertheless, in recent years investment tribunals most often make use of income based approaches, including the DCF method, which may result in higher damages. ${ }^{76}$

72 Richard E. Walck, "Methods of Valuing Losses" in M. Bungenberg, J. Griebel, S. Hobe and A. Reinisch (eds.), International Investment Law - A Handbook (2015) pp. 1046-1047.

The World Bank Guidelines contain the following definition of the DCF: "the cash receipts realistically expected from the enterprise in each future year of its economic life as reasonably projected minus that year's expected cash expenditure, after discounting this net cash flow for each year by a factor which reflects the time value of Money, expected inflation, and the risk associated with such cash flow under realistic circumstances. Such discount rate may be measured by examining the rate of return available in the same market on alternative investments of comparable risk on the basis of their present value." $<$ http://documents1.worldbank.org/curated/en/955221468766167766/pdf/multi-page .pdf $>$ accessed on 11/10/2020.

74 Irmgard Marboe, Calculation of Compensation and Damages in International Investment Law (2nd ed., 2017) p. 235. Metalclad Corporation v. The United Mexican States, ICsid Case No. ARB(AF)/97/1, Award, 30 August 2000, para. 121. CME Czech Republic B.V. v. The Czech Republic, UnCitral, Separate Opinion on the Issues at the Quantum Phase of: CME v. Czech Republic by Ian Brownlie, 13 March 2003, paras. 97-100. Starrett Housing Corporation v. Iran, Final Award, (1987) 16 Iran-US CTR 112. Phillips Petroleum Company Iran v. Iran, Award, (1989) 21 Iran-US CTR 79, paras. 111-113. ADC Affiliate Limited and ADC \& ADMC Management Limited v. The Republic of Hungary, ICSID Case No. ARB/o3/16, Award of the Tribunal, 2 October 2006, para. 502.

75 ILC, Articles on State Responsibility, with commentaries, Article 36, para. 26. <http:// legal.un.org/ilc/texts/instruments/english/commentaries/9_6_2001.pdf> accessed on 19/o7/2019. Martins Paparinskis, "A Case Against Crippling Compensation in International Law of State Responsibility" Modern Law Review (2020), p. 14.

76 Antin Infrastructure Services Luxembourg S.à.r.l. and Antin Energia Termosolar B.V. v. Kingdom of Spain, ICSID Case No. ARB/13/31, Award, 15 June 2018, para. 688. Eiser Infrastructure Limited and Energía Solar Luxembourg S.à r.l. v. Kingdom of Spain, ICSID Case No. ARB $/ 13 / 36$, Award, 4 May 2017, paras. 441 and 465. EDF International S.A., SAUR International S.A. and León Participaciones Argentinas S.A. v. Argentine Republic, ICSID Case No. ARB B/o3/23, Award, 11 June 2012, paras. 1242-1243. Gold Reserve Inc. v. Bolivarian Republic of Venezuela, ICSID Case No. ARB(AF)/o9/1, Award, 22 September 2014, para. 832. Irmgard Marboe, Calculation of Compensation and Damages in International Investment Law (2nd ed., 2017) pp. 236-237. Kai F. Schumacher and Henner Klönne, "Discounted Cash Flow Method" in Christina L. Beharry (ed.), Contemporary and Emerging Issues on the Law of Damages and Valuation in International Investment Arbitration (2018). Chin Leng Lim, Jean Ho and Martins Paparinskis, International Investment Law and Arbitration Commentary, Awards and Other Materials (1st ed., 2018) pp. 410-417. Floriane Lavaud and 
At times, States may object to this practice. In the Masdarv. Spain case for instance, Spain argued that the DCF method was inappropriate, amongst others because the Spanish Supreme Court refuses its application. ${ }^{77}$ The tribunal rejected this argument, stating that it was engaged in the application of international law and referred to the acceptance of the DCF method in investment treaty jurisprudence. ${ }^{78}$

In relation to the two aspects named above, approaches recently adopted by several investment tribunals deviate from the approaches adopted in the past by international courts and tribunals. Of course, it cannot be said, in abstracto, that this is problematic or wrong since the individual circumstances of each case should be taken into account and the law of State responsibility itself may be subject to change and development. ${ }^{79}$

Nonetheless, the self-referential nature of investment arbitration jurisprudence and the implications that it may have on taxpayer's money seem to be significant and neglect to appreciate the public law nature of investment disputes.

Guilherme Recena Costa, "Valuation Date in Investment Arbitration: A Fundamental Examination of Chorzów's Principles", 3Journal of Damages in International Arbitration (2016) p. 35. The benefits of using the DCF method, which allow the user to value an investment on the basis of its future capability to generate income, were already explained by Lieblich many years before investment tribunals would actually apply it, see: William Lieblich, "Determining the Economic Value of Expropriated Income-Producing Property in International Arbitrations", 8 Journal of International Arbitration (1991), pp. 74-75.

77 Masdar Solar \& Wind Cooperatief U.A. v. Kingdom of Spain, ICSID Case No. ARB/14/1, Award, 16 May 2018, paras. 569-580.

78 Ibid paras. 575 and 580 . The rejection of the relevance of domestic court jurisprudence may be striking given the fact that international courts and tribunals sometimes explicitly look at domestic practice and/or court jurisprudence for guidance. See: Certain Activities Carried out by Nicaragua in the Border Area (Costa Rica v. Nicaragua) Judgment of 2 February 2018, Compensation owed by the Republic of Nicaragua to the Republic of Costa Rica, I.C.J. Reports 2018, paras. 35 and 52. Trail Smelter case (United States $v$. Canada), 16 April 1938 and 11 March 1941, United Nations, Reports of International Arbitral Awards (RIAA), Vol. III, p. 1920. Story Parchment Co. v. Paterson Parchment Paper Co., 282 U.S. 555 (1931), para. 7 .

79 See for example: $A D C$ Affiliate Limited and $A D C \& A D M C$ Management Limited $v$. The Republic of Hungary, ICSID Case No. ARB/o3/16, Award of the Tribunal, 2 October 20o6, paras. $496-497$. 
To answer this article's research question, a review of ECT awards demonstrates that ECT tribunals have a decided preference to utilize teleological interpretive tools to give content to the CIL standard of full reparation.

Turning to the application of that norm, it is in this third stage of the lifecycle' of the CIL rules of reparation where one may subsequently find the answer to the 'million-dollar question' in investment arbitration. A teleological interpretation of 'full reparation' may lead to a level of compensation with which many (inter)national public courts may feel uncomfortable.

Arguably, if a purpose of investment treaties is to ensure that a level-playing field exists between domestic and foreign investors, the current practice of investment tribunals concerning reparation may actually tilt the playing field in favour of foreign investors.

One may ponder whether this is actually the purpose of the 'full reparation' norm. Perhaps the critical remarks of the ILC concerning 'full reparation' and compensation could be considered a bit more carefully by investment tribunals. ${ }^{80}$ After all, showing restraint when applying a norm does not necessarily prejudice the teleological interpretation given to that norm. A failure to do so might, in the long run, undermine the wide acceptance of the norm and/ or give rise to the introduction of exceptions thereto. ${ }^{81}$ This critical remark is all the more pertinent in light of the ostensible rise in the number of billion dollar plus awards rendered by investment tribunals in recent years. ${ }^{82}$

8o ILC, Articles on State Responsibility, with commentaries, Article 36, para. 26. <http:// legal.un.org/ilc/texts/instruments/english/commentaries/9_6_2001.pdf> accessed on 19/07/2019.

81 Various recent investment treaties or investment related instruments indicate, for example, that monetary damages shall not be greater than the loss suffered by the claimant, see: Article 22(4), Netherlands Model Bilateral Investment Treaty, 2019. Article 3.18(2), European Union-Singapore Investment Protection Agreement (European Union-Singapore) (adopted 15/10/2018, entrance into force still pending). Article 8.39(3), Comprehensive Economic and Trade Agreement (European Union-Canada) (adopted 30/10/2016, entrance into force still pending). Article 3.53(2), European Union-Viet Nam Investment Protection Agreement (European Union-Viet Nam) (adopted 30/06/2019, entrance into force still pending). See also: Martins Paparinskis, "A Case Against Crippling Compensation in International Law of State Responsibility" Modern Law Review (2020), p. 6.

82 Occidental Petroleum Corporation and Occidental Exploration and Production Company v. the Republic of Ecuador, ICSID Case No. ARB/o6/11, Award, 5 October 2012. Occidental Petroleum Corporation and Occidental Exploration and Production Company v. the Republic of Ecuador, ICSID Case No. ARB/o6/11, Decision on Annulment 


\section{Acknowledgements}

The views expressed in this article are solely mine and cannot be attributed to Pels Rijcken and/or its clients. Furthermore, I would like to express my gratitude to the reviewers, P. Merkouris and M. Fortuna for their valuable feedback on earlier drafts of this article. Any errors remain my own.

of the Award, 2 November 2015. ConocoPhillips Petrozuata B.V., ConocoPhillips Hamaca B.V. and ConocoPhillips Gulf of Paria B.V. v. Bolivarian Republic of Venezuela, ICSID Case No. ARB/o7/3O, Award, 8 March 2019. 